After graduating from the Imperial College of Science and Technology in 1943, Dr. Zienkiewicz conducted. research into some problems of gravity dam design under Profs. A. J. S. Pippard and R. V. Southwell at the same institution. In 1945 he joined Sir William Halcrow and Partners, and for four years he gained experience in the design and construction of dams and hydro-electric projects. He was then appointed a lecturer in civil engineering at the University of Edinburgh where he remained until 1957, when he joined the staff at Northwestern University, Evanston, as an associate professor, becoming a full professor in 1960. Dr. Zienkiewicz's research interests have ranged widely, embracing both fluid mechanics and stress analysis. Apart from his work on gravity dams, several of his early papers were concerned with the behaviour of surge waves and with problems of hydrodynamic lubrication. His main interest at present is in the field of thermal stress analysis in elastic and viscous materials, and he is investigating applications to the design of concrete dams, reactor shields and other shell structures. Several lines of approach are being considered, notably structural models and analogue methods as well as analytical and numerical procedures. The building of new accommodation for all the Depart. ments of Applied Science is to commence at Swansea in 1962. Dr. Zienkiewicz will therefore have the opportunity to plan further developments in civil engineering, specially suited to his own research interests, and he must also establish arrangements for teaching the much greater number of undergraduates to be admitted in the near future. His colleagues in this task will be Prof. R. H. Macmillan (Mechanical Engineering) and Prof. W. Fishwick (Electrical Engineering), now chairman of the Department.

\section{Zoology at Ghana :}

Prof. E. E. Edwards

Prof. E. E. Edwards, who retired this year from the chair of zoology at the University College of Ghana, has become director of a new Entomological and Parasitological Research Unit under the National Research Council established by the Ghana Government in 1958. He will therefore be able to continue his interests in tropical entomology and parasitology which were a feature of the University Zoology Department under his professorship. $\mathrm{He}_{\theta}$ was appointed to Achimota, then the University College of the Gold Coast, in 1952, and during his occupancy of the chair was responsible for the planning of the zoological laboratories at the new Legon site of the College.

Prof. R. D. Purchon

Prof. R. D. Purchon, who has now been appointed to succeed Prof. Edwards, goes to Ghana from the chair of zoology at the University of Malaya in Singapore, which he has held for eleven years. During that time he established a very active school for the study of the animal ecology of Malaya, with particular emphasis on marine biology. Facilities for this type of work are already well founded in Ghana, where Accra has served as a centre for much of the previous work of the University College in this field.

\section{British Participation in Space Research}

IN asking leave of the House of Commons on March 21 to introduce a Bill to provide for the establishment of a Minister of Space Research and Development, and for connected purposes, Mr. Woodrow Wyatt argued that no real progress in this important new field would be made until Britain had a Minister in the Cabinet responsible for co-ordinating everything to do with space. The Americans were spending $£ 310 s$. a year per head of their population on space development, and the Russians an equivalent sum because they knew that the resultant advances in technology would be injected into other branches of industry. Britain, however, was spending not more than $1 d$. per head, and to fall 3 or 4 years behind in any department gravely handicapped technologists and made their task of keeping Britain in the forefront more difficult. Mr. Wyatt asserted that too many Ministries had a fringe interest and none an overriding concern in space matters, and that the Minister for Science was not sufficiently interested. He referred to the profit to be made out of communication satellite systems, but alleged that effort was being duplicated and that the Postmaster-General was indifferent to the work being done in this field by firms like the English Electric Co., HawkerSiddeley, and Pye, and maintained that the future of Britain's export trade and her standard of living depended on not being left out of the space age. Leave to introduce the Bill was granted and the Second Reading ordered for May 5.

\section{British Funds for Oceanographic and Hydrographic Research}

At the Committee stage of the Navy Estimates 1961-62 in the House of Commons on March 14, several questions were raised on the vote of $£ 21$ million for scientific services, an inerease of $£ 1 \cdot 7$ million. This represents about 5 per cent of the Navy Vote of $£ 400$ million, but Mr. C. Ian Orr-Ewing, Civil Lord of the Admiralty, admitted that the true expenditure on research and development was considerably more, including expenditure incurred through the Ministry of Aviation. The 98-in. Isaac Newton telescope now being erected at Herstmonceux would cost about $£ 780,000$, of which half would come from Navy Votes and half from the Treasury, and it would not only be used by the Royal Greenwich Observatory, but would also be available for general use by other astronomers in the United Kingdom. Replying to specific questions about hydrographic work, Mr. Orr-Ewing said that R.R.S. Discovery II would cost some $£ 570,000$ this year, of which $£ 285,000$ would come from the Navy Vote and $£ 285,000$ from the Development Fund. Its maximum range would be 15,000 miles and its cruising speed would be $9-10$ knots. It would be $260 \mathrm{ft}$. long with a loaded draught of $18 \mathrm{ft}$., and it was planned to have a scientific plotting room at deck-level; electronic hydrographic, biological, chemical and general labora. tories, a low-temperature laboratory and an underwater instrument room with a trunk leading through the bottom of the ship. About the same amount as last year would be spent on research and development of nuclear propulsion, but there was a considerable increase in salaries, wages and allowances, resulting from adjustments to keep those of the scientific staff with salaries of scientists in industry and elsewhere. The vote included a grant-in-aid to the National Institute of Oceanography and a subscription to the International Hydrographic Bureau. 